\title{
"The interplay of competition, regulation and stability: the case of Sub-Saharan African commercial banks"
}

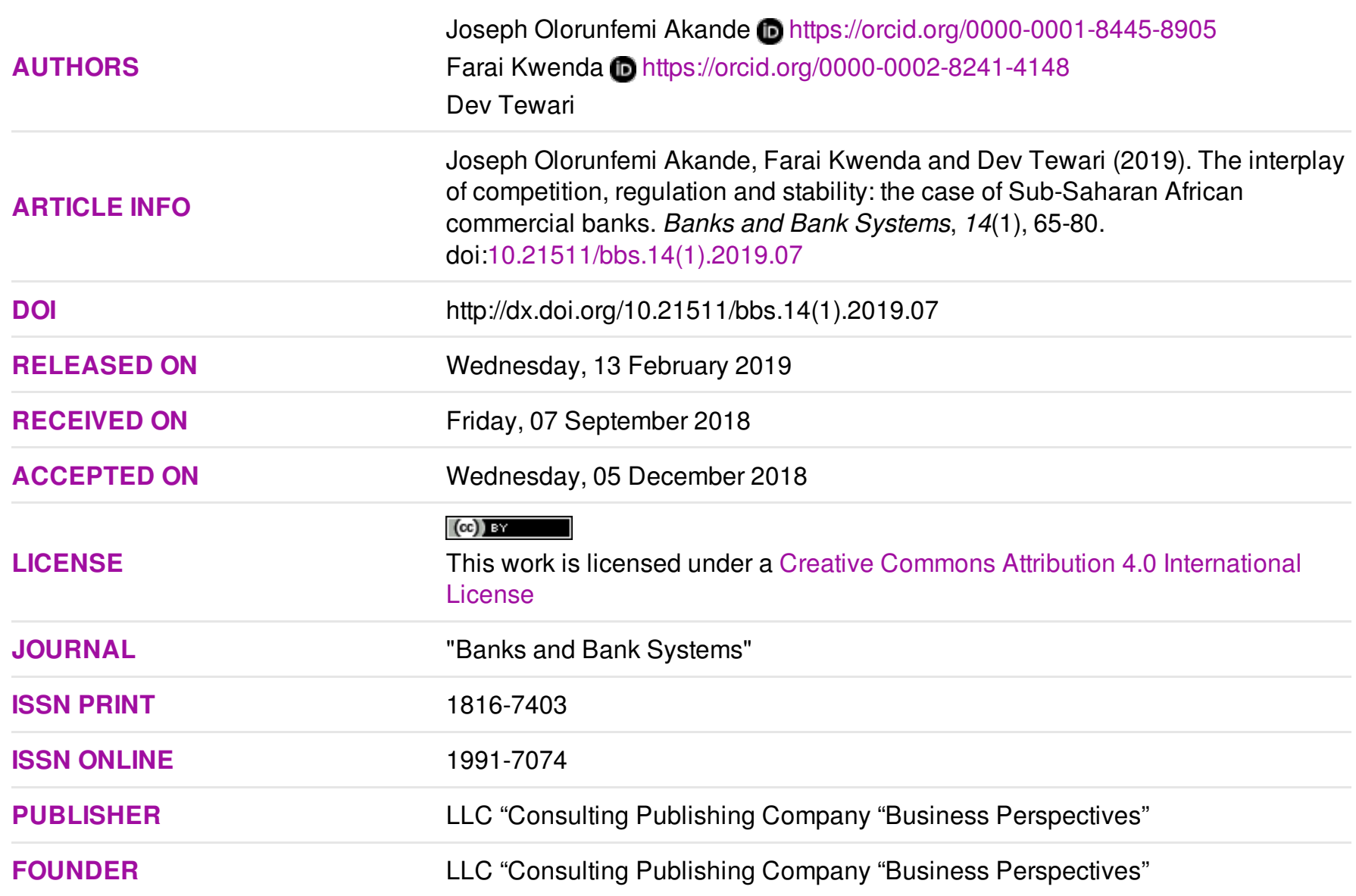

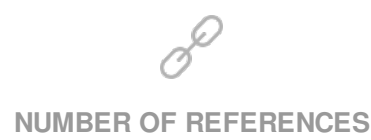

72
NUMBER OF FIGURES

2
NUMBER OF TABLES

5

(C) The author(s) 2022. This publication is an open access article. 


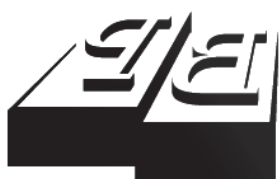

BUSINESS PERSPECTIVES

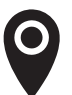

LLC "CPC "Business Perspectives" Hryhorii Skovoroda lane, 10, Sumy, 40022, Ukraine

www.businessperspectives.org

Received on: $7^{\text {th }}$ of September, 2018 Accepted on: $5^{\text {th }}$ of December, 2018

(C) Joseph Olorunfemi Akande, Farai Kwenda, Dev Tewari, 2019

Joseph Olorunfemi Akande, Accounting, Economics and Finance, Namibian University of Science and Technology, Windhoek, Namibia, Ph.D. in Finance, Postdoctoral Fellow University of Zululand, South Africa.

Farai Kwenda, Ph.D. in Finance, Research Associate, University of KwaZulu-Natal, South Africa.

Dev Tewari, Professor, Ph.D. in Economics, University of Zululand, South Africa.

\section{(c) (1)}

This is an Open Access article, distributed under the terms of the Creative Commons Attribution 4.0 International license, which permits unrestricted re-use, distribution, and reproduction in any medium provided the original work is properly cited.
Joseph Olorunfemi Akande (Namibia, South Africa), Farai Kwenda (South Africa),

Dev Tewari (South Africa)

THE INTERPLAY

OF COMPETITION, REGULATION AND STABILITY: THE CASE OF SUB-SAHARAN AFRICAN COMMERCIAL BANKS

\begin{abstract}
Stimulating competition in the banking system without compromising stability constitutes a major puzzle that bank regulators and practitioners face. Hitherto, empirical studies focusing on Sub-Saharan Africa in addressing these issues for the anticipated regional integration and sustainable growth are rare. This study applied structural equation modelling to simultaneously analyze competition, regulation and stability in a panel of 440 Sub-Saharan African commercial banks over the period from 2006 to 2015. The results provided evidence that competition affects stability via efficiency and that regulation affects stability via competition and efficiency. This study produced critical theoretical and methodological insights with substantial implications for the conduct of bank regulatory policy.
\end{abstract}

\section{Keywords}

JEL Classification

commercial banks, competition, stability, regulation, structural equation modelling

B26, C58, G21

\section{INTRODUCTION}

A healthy interplay of competition, regulation and stability is key to managing a bank system that impacts the development of an economy. The economic reality of the Sub-Saharan Africa (SSA) region is that it has a high economic growth rate in terms of GDP ${ }^{1}$ (IMF, 2016; World Bank, 2017). However, this high economic growth rate does not translate to development, as larger proportion of the people still live in abject poverty and deprivation (Watkins, 2014). The situation is exacerbated by low financial intermediation the impacts of economic gains from getting to the people. The available banks are inaccessible by low income group because of excessive cost of borrowing and service charges, which are attributed to lack of competition in the financial system, as in most countries, three to five banks account for the bulk of the financial assets of financial systems (Mlachila et al., 2013). Financial inclusion is dismally low with a number of adults to a bank branch overwhelmingly high (Beck \& Cull, 2013; Mehrotra \& Yetman, 2015). Although competition is good in a bank system because of its potential to lead to efficient banks that could ameliorate some these problems (Casu, Girardone, \& Molyneux, 2015), however, if not managed properly, it could result in financial system instability. Fu, Lin, and Molyneux

1 Tied majorly to high commodity prices. 
(2014) provided evidence that excessive competition played a significant role in the 2007-2009 world financial crisis despite regulatory efforts at both international and national levels.

Regulation has been long debated in the banking industry and the events leading to the 2007-2009 financial crises have increased attention to bank regulation across the globe (Allen \& Carletti, 2013). The SSA banking systems have witnessed remarkable reforms culminating in various forms of regulations. The thrusts of these reforms that took place in different countries at different times were interest rates liberalization, credit control removals, consolidation, deregulations and prudential management, among others, with focus on more capitalized banks. According to Casu, Girardone, and Molyneux (2015) and Llewellyn (1999), the essence of regulating the banking system is to eliminate monopolistic exploitative tendencies while maintaining the stability of the system. Regulation does not only stimulate competition, but also helps in moderating the excessiveness of competitive activities, as the potential instability that could result in excessive competition often constitutes part of the agitations for banking regulation (Angkinand, 2009; Barth, Caprio, \& Levine, 2004; Carletti, 2008; Cihak, Demirgüç-Kunt, Martınez Peria, \& Mohseni-Cheraghlou, 2012; Dell'Ariccia \& Marquez, 2006). However, the interrelationship among competition, regulation and stability is not clear in literature. More so that, Agoraki, Delis, and Pasiouras (2011) found that the stabilizing power of regulation diminishes when banks have enough market power to increase credit risk and is reversed for banks that possess moderate market power. Moreover, despite the reforms implemented by SSA countries, their banking sectors are highly concentrated (Mlachila et al., 2013) and potentially unstable due to high incidences of non-performing loans, which are on the increase.

Banking competition brings about a stable and efficient banking sector where there is access to finance, low charges and moderate interest rates spread (Chirwa, 2003; Freixas et al., 2008; Kouki \& Al-Nasser, 2014; Mugume, 2008; Ariss, 2010). However, service charges and lending rates are extremely high with meager deposit interest rates in SSA banking sectors (Mlachila, Park, \& Yabara, 2013). Moreover, high NPLs threaten the stability of the banks in the region. Despite some of the efforts to regulate the sector, these problems have persisted. High costs of banking and lending rates are being identified as factors militating against banking sectors' financial intermediation role. Consequently, service charges are high, financial intermediation is low and high interest rate spreads stifle investment and savings, curtailing the efficient operation of banks in this region, hence, their inability to finance SSA countries' developmental goals. These pose the enormous challenges of the place of regulation in addressing competition in banking without sacrificing stability of the sector to policy makers. According to Vives (2016a), regulation in terms of conduct and structure has the capacity to alleviate the competition-stability trade-off, but not eliminate it. Matutes and Vives (2000) and Vives (2014) agree that capital requirements need to be tougher with more intense competition, but how well to do this has remained unresolved. This study therefore contributes to literature in this area, as it investigates the interrelationship between competition, regulation and stability in the banking system.

Thus, we applied Structural Equation Modelling (SEM) to simultaneously analyze competition, regulation and stability in banks and showed that competition affects stability via efficiency and that regulation affects stability via competition and efficiency. We produced critical theoretical and methodological insights with substantial implications for the conduct of bank regulation policy. Given the key findings here, to the best of our knowledge, this is the first study of this nature. The rest of the paper is organized as follows: the literature review, theoretical and empirical, is presented in section 1. Section 2 explains the method adopted including data source and description of variables used. Section 3 presents the results, the summary and conclusion are presented in the last section. 


\section{LITERATURE REVIEW}

\subsection{Competition and stability}

Competition is a complex phenomenon in the bank system. The contestable market theory (Abdelkader \& Mansouri, 2013) and the competition-stability hypothesis argue that competition will result in stability. The competition-stability hypothesis envisages an efficient bank system capable of orchestrating the stability of the bank system (Schaeck \& Čihák, 2014). However, overwhelming evidence exists in literature on whether competition is good or bad for the bank system resulting in two opposing views - competition-stability and competition-fragility views (Ariss, 2010; Boyd, De Nicolo, \& Jalal, 2009; Fu et al., 2014; Schaeck \& Čihák, 2014). Attempting to reconcile this trade-off/dichotomy has in the past occasioned regulatory efforts. Although structural and non-structural models underlying the thinking for a competitive bank system differ in measurements, they converge on the idea that the structure of banks determines their performance (Bresnahan, 1982; Demsetz, 1973; Hicks, 1935; Shepherd, 1983, among others). Based on the market structure theories, a competitive bank system is expected to be efficient at financial intermediation given that they are compelled to innovate and attract customers that are supposedly faced with alternative choices. Hence, a competitive banking environment should produce a stable bank as argued by the authors of the competition-stability view (Boyd et al., 2009; Schaeck \& Cih'ak, 2014, among others). They argue that competition is good, since it is consistent with efficiency, which thus enhances the stability of the banking system. The welfare theorem presupposed by these theories is however associated with pure competition whose features impede optimal resources utilization in the industry, resulting in varying levels of inefficiency. Thus, the obvious reality of the banking industry where price is in most banking lines not equal to marginal cost nor is there free entry and exit plus the presence of differentiated products, make pure competition inappropriate. This can be inferred in the traditional competition-fragility theorist's arguments that excessive competition destabilizes the bank system (Beck, De Jonghe, \& Schepens, 2013; Fu et al., 2014, among others). According to these authors, high competition in banking causes banks to lose their market powers, culminating in declining profitability. Hence, they become aggressive to invest in riskier portfolios to recoup the financial losses. Therefore, the proponents of this view posit that this risk-taking behavior will erode bank system's stability. Boyd and De Nicolo (2005), considering the assets side of banks' balance sheets, argue that the risk-shifting effects of banks market power in less competitive market are the ultimate cause of instability in banks as their loan portfolio riskiness rises. MartinezMiera and Repullo (2010) concur with this view, but add that the higher interest rate charged improves the bank's profitability, that is, the margin effect and, as such, presents a U-shaped argument in the competition and stability relationship.

\subsection{Competition, regulation and stability}

These opposing views of competition and stability relationship presuppose regulatory implications. Finance and economic theories seem to have divergent views on the issues of competition, regulation and stability in the bank system without any of them combining these phenomena. In a review of theoretical and empirical literature, Vives (2016b) concludes that competition is not in any way the reason for fragility in the bank system. While he admits that the existence of heightened competitive banking environment could aggravate the situation, instability in banks and systemic failure in general is a subject of certain banking fundamentals. In other words, banks may fail not necessarily because of competition, hence, highlighting the place of regulation. Hakenes and Schnabel (2011) conducted a theoretical review of capital regulation, competition and stability in banks to analyze capital requirements in situations where banks compete on both the assets and liabilities sides of their balance sheets. They concluded that the ambiguous effects of competition on bank risk taking translate to ambiguous effects of capital requirements on financial stability, as banks chose the correlation of their loans' portfolio. The authors further argued that capital can hurt stability because of its influence on competition. In other words, the stabilizing effect of capital regulation tends to be effective in those situations where the charter value effect dominates, and vice versa. Their model suggests that capital regulation may 
not be suited in all circumstances to prevent excessive risk-taking in banking. On the other hand, Kim and Santomero (1988), in a single-period mean-variance model of the role of capital in risk control, argue that simple capital ratio regulation is ineffective in ameliorating banks' likelihood of insolvency risk, because it ignores the individual banks' different preference structures and allows risky banks to circumvent the restriction via financial leverage and/or business risk. Bolt and Tieman (2004) did a theoretical dynamic modelling of demand for loan to examine the interaction of competition, bank risk-taking and regulation and concluded that increased competition in the banking industry leads to riskier banking behavior. They argue that it is more beneficial for banks to hold more equity than prescribed by regulators, as the more intense the competition, the greater the risk-taking by commercial banks, the higher the failure rates, hence, the charter value falls.

Hellmann, Murdock, and Stiglitz (2000) concluded that if the liability side of bank balance sheets are competitive enough, banks will invest in risky assets, because, as banks compete for insured deposits, they are able to invest in conservative or in volatile assets while raising outside capital. However, banks are closed if capital becomes negative. Though not an efficient means, as capital decreases banks' franchise value, but they argued that it helps to restore incentives to invest in prudent assets by imposing high capital requirements. According to these authors, this explains the superiority of deposit regulation in contrast to capital regulation in excessive competition control. Modelling competition for deposits with banks utilizing internal capital, Repullo (2004) insists that deposit regulation does not outperform capital regulation. Advocating minimum capital regulation, Allen and Gale (2004), in a general equation model of financial intermediaries and markets with spatial competition and Schumpeterian competition including contagion, concluded that perceived trade-off between competition and stability arising from the allocative efficiency, which is associated with competition, increased the calls for regulation to ensure the coexistence of competition and stability. The authors argue that the most important means to strike the necessary bal- ance is to impose minimum capital regulation on banks, as this will reduce the capital available to them; thus, curtail their risk appetite and compete fairly.

Competition and stability have been argued to be the essence of regulations in the banking sector (Casu et al., 2015). More recent literature is now converging on the views that competition is not the cause of fragility in the bank system, but that its presence, especially when in excess, aggravates the risk of instability (Vives, 2016a). It suggests a structural approach to holistically manage the coexistence of these phenomena. Empirical literature as reviewed both within and beyond the SSA region has used a number of methods to test this relationship, but none have achieved a structural analysis where both competition, regulation, and stability are investigated simultaneously. In addition, emphasis on regulation has been largely limited to capital with little or no considerations for liquidity and asset quality regulations as now contained in the expanded Basel Accord, as well as the bank CAMEL ${ }^{2}$. This is the contribution this study seeks to make to literature by not only incorporating the role of liquidity and asset quality regulation, but also structurally investidate the channels among the variables within the bank system, hence, answer why and how the relationship exists. Hence, the ability to capture the variables simultaneously to analyze both the direction of causality and the direct and the indirect relationship using SEM, thus filling the critical theoretical and methodological gap in literature on the conduct of bank regulation policy. This way, the trio of competition, regulation and stability could be better managed in the bank system for optimal performance.

\section{METHODOLOGY}

We modelled the relationship between competition, regulation and stability as well as considered the mediation roles of competition and efficiency in the structure as shown in Figure 1, using the SEM.

Given the foregoing literature, Figure 1 hypothesizes the expected relationship between the var-

2 Capital adequacy, Asset quality, Management, Earnings, and Liquidity. 


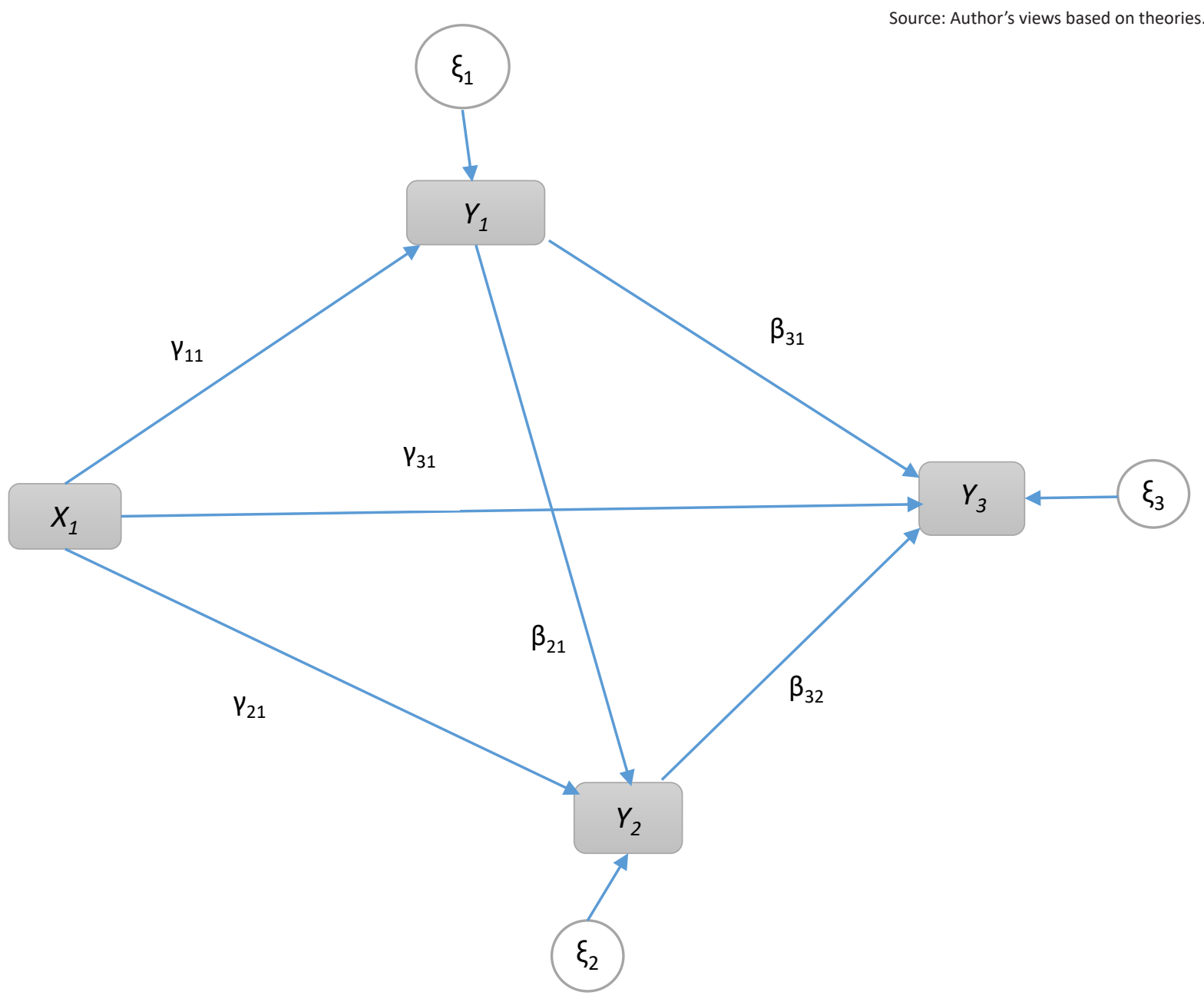

Figure 1. Possible recursive path model for CRS

iables. We expect regulation to directly impact competition, efficiency and stability, on the one hand, and an indirect effect on stability through, competition and efficiency. Furthermore, competition and efficiency are also expected to each independently have direct effects on stability, while competition does also indirectly affect stability. These are represented by the paths in Figure 1 such that $X_{1}$, representing regulation variables, is exogenous to the structure, $Y_{1}$, competition, and $Y_{2}$, efficiency, are both exogenous and endogenous variables while, $Y_{3}$, stability, is an endogenous variable. Given that the path diagram represents a set of univariate regression equations, the structural coefficient in the structural model variables equals the regression coefficient with $\beta$ representing the structural effects of endogenous variables on other endogenous variables and $\gamma$ representing the structural effects of exogenous variables on endogenous variables.
Hence, we summarized the relationship in the reduced form of SEM model following Chang, Lee, and Lee (2009) and Mueller (1999) as follows:

$$
Y=B Y+\Gamma X+\alpha+\xi,
$$

where $Y$ represents $(N Y \times 1)$ column vector of endogenous variables, competition, efficiency and stability, $X$ is a $(N X \times 1)$ column vector of exogenous variables, regulation (capital, liquidity and assets quality regulations), $B=\left[\beta_{i j}\right]$ represents the matrix of coefficients of endogenous predicting other endogenous variables, $\Gamma=\left[\gamma_{i j}\right]$ is the coefficient of exogenous matrix to endogenous variable, $\alpha=\left[\alpha_{i}\right]$ is column vector of intercept of endogenous variables, $\xi$ represents $(N Y \times 1)$ column vector of error terms of endogenous variables, $N Y$ is the number of endogenous variable, $Y$, while $N X$ is the number of exogenous variables. The coefficient of $B$ matrix is used to explain the direct effects of one endogenous variable 
on another endogenous observed variable that are associated with the two variables. The $\Gamma$ matrix associated with the two variables defines the structural coefficient of direct effects of exogenous on endogenous observed variables. The indirect effect between two observed variables through a particular mediating variable is then the product of the structural coefficients in the $B$ and/or $\Gamma$ matrices along the particular path from the exogenous to the endogenous variables. Therefore, the total indirect effect between two observed variables is the sum of all particular indirect effect through all possible mediating variables. The sum of the direct and total indirect effect components between two observed variables is defined as the total effect as contained in Figure 1.

Concerning SEM, it consists of a vast litany of models, from linear regression model to measurement models and simultaneous equations, providing the possibility of capturing the contemporaneous and simultaneous relationship among variables. SEM therefore is a way of estimation, which is not constrained by any kind of model; a multivariate method that permits the system of equation estimation. Moreover, the power also lies in the ability to measure both direct and indirect causal effects among structural variables, hence, the mediation analysis, thereby allowing chains of conditional relationships to be fitted via path analysis. According to Li (2011), SEM has the capability to control for measurement error and is accordingly able to take on the effects of multiple mediators that are applicable to this study, thus, a utility model most effective in testing mediating effects. Furthermore, with SEM model, the direct and indirect effects in the path diagram of competition, regulation and stability can be estimated. Once found to be fit and stable, the strength of SEM lies in determining the path of causality in a structure with the ability to simultaneously deal with multiple endogenous and exogenous variables in addition to the mediating analysis described above.

\subsection{Data source and variable description}

In this study, 440 banks from 37 SSA countries ${ }^{3}$ (see Appendix A) with 3,165 observations for the period from 2006 to 2015 are considered. Data used are sourced from the BankScope ${ }^{4}$ database compiled by Fitch/IBCA Bureau van Dijk. The main variables of interest for the proposed model of competition, regulation and stability nexus in the SSA commercial banks include capital regulation, liquidity regulation, asset quality regulation, bank level competition, efficiency and stability.

We consider bank level competition more appropriate for this study to gauge the relative market power of individual commercial bank in the SSA banking market. Hence, the choices of Lerner index adjudged as the best in short-term competition estimation, including estimation of bank level competition, and predicated on sound economic theory (see Berger, Klapper, \& Turk-Ariss, 2008; Demirgüç-Kunt \& Peria, 2010; Liu \& Wilson, 2013; Rojas, 2011, among others). Our estimation of Lerner index follows the study of Berger et al. (2008) as the difference between the price and marginal cost divided by price, with the marginal cost being a derivation of the translog production function to produce translog cost function through the second-order Taylor series expansion of bank costs in natural log, and price proxied by the ratio of bank total revenue to total assets (see Berger \& Udell, 2004; Carbó, Humphrey, Maudos, \& Molyneux, 2009, among others). Relevant data for the estimation of Lerner index, the proxy for competition and/or market power are interest expenses, personnel expenses, non-interest expense and total revenues. This study considered interest expenses based on Tan (2013), Wang, Zeng, and Zhang (2014) to include interest on time deposits, savings accounts, current accounts, alternative funding sources such as retail bonds and repurchase agreement. Wages and salaries, pension funds contributions, contributions to social securities plus other labor related expenses were included in the data collected for personnel expenses in line with Delis, Staikouras, and Varlagas (2008). For non-interest expenses, data considered based on banks' profile largely include expenses relating to administration - such as service charges, communication and information systems, rents, professional charges, insurance and other office expenses, including depreciation; and selling and distribution expenses that cover publicity,

3 This excludes South Africa due to its more advanced and sophisticated banking system (Allen, Otchere, \& Senbet, 2011; Senbet \& Otchere, 2006) to avoid structural imbalance in the analysis.

4 BankScope is a popular database used in most banking sector research in literature. 
advertising and transportations. There is growing literature agreeing to the inclusion of non-interest income in the revenue data requirements for Lerner index estimation based on the argument that such revenue has increased significantly in the recent times as a component of banks earnings (see Ajisafe \& Akinlo, 2013; Berger et al., 2008; Prasad \& Ghosh, 2005, among others), hence, the inclusion of both interest and non-interest revenues and other operating income data.

Like most studies on bank stability (Kouki \& AlNasser, 2014; Laeven \& Levine, 2009; Lepetit \& Strobel, 2013), this study uses the Z-score as a surrogate for stability. The Z-score is a measure of the extent to which banks profit must fall before their equity becomes negative. In essence, it is a measure of the probability of banks' insolvency and therefore encompasses the banks' overall risk, hence, considered as an appropriate stability measure of banks. In the case of efficiency, we used the stochastic frontier analysis (SFA) to generate the efficiency scores of banks using Frontier version 4.1 (Coelli, 1996), a computer program based on stochastic production functions of Battese and Coelli $(1992,1995)$ written to provide maximum likelihood estimates of different types of stochastic frontier production as independently introduced by Aigner, Lovell, and Schmidt (1977) and Meeusen and van Den Broeck (1977). It accounts for truncated normal assumption, including panel data with time varying efficiencies. Hence, applicable to our unbalanced panel model with firm effects having truncated normal random variables distribution assumption that can vary systematically with time (Battese \& Coelli, 1992). The necessary data collected for implementing the output-oriented stochastic frontier analysis include banks pre-tax income as used by Chiou and Porter (2015) and asset book value based on J. Barro and R. Barro (1990) as input and output variables. The choice of regulatory variables is contemplated by the main coverage of the Basel Accord and the bank CAMEL on which adequate data could be sourced. Hence, our regulatory capital is the equity capital ratio (ECR), which, according to Casu et al. (2015), constitutes one of the three measures of bank capital regulations. Liquidity (LQTY) regulatory variable used is the ratio of bank liquid assets to depreciation and short-term funds; according to Moyo, Nandwa, Council, Oduor, and
Simpasa (2014), by regulation, it dictates the level of liquid assets banks must hold to meet their routine obligations including the funding of their loan assets. Furthermore, the quality of bank assets portfolio is another highly regulated aspect of banking. We proxy asset quality (AQLTY) regulatory variable with loan loss reserve to net loan assets, which serves as health check for banking assets in terms of the proportion of performing loans with implication for bank's performance and bank's stability.

\section{RESULTS}

Appendix B presents the summary statistics of the data used; it provides a brief insight into the nature of the data. The main essence of data distribution in Appendix B is to satisfy the thresholds for implementing the SEM model. Overall, the data are normally distributed as confirmed by the JarqueBera statistics in Appendix B validating the use of SEM. Once the model is found to be fit, the expectation is a structural banking model where regulation, competition, efficiency and stability simultaneously interplay to provide insight into how best to manage the well-being of the bank system. This suggests that none of the variables can be treated in isolation, as a decision made on one will have a ripple effect on all the other variables in the system. We presented a proposed recursive CRS model in Figure 1 in section 2 for the commercial bank system of the SSA region. The estimated version of this model is shown in Figure 2, which for SEM contains six observed variables, consisting of three observed exogenous variables, ECR, LQTY and AQLTY, as well as three observed endogenous variables, LERNERI, EFF and ZSCORE. Observed exogenous variables are variables with datasets that are determined outside the model and for the sake of the bank system, issues of regulations are largely exogenously handled. These variables have no arrows pointing at them in the model and they are known as independent variables. Observed endogenous variables also known as dependent variables represent variables with datasets that are determined within the system. The pointed arrows show the directions of causality and the estimates on the path represent the standard coefficients estimates generated using STATA 13. Hence, SEM provides an opportunity to model the bank sys- 
Table 1. Data measurement model fit

Source: Authors' estimation, 2018, based on SEM Global Fitness Criteria ${ }^{5}$.

\begin{tabular}{l|c|c|c|c|c|c}
\hline \multicolumn{1}{c|}{ Model fit indicators } & LR Prob $>$ chi2 & RMSEA & PCLOSE & SRMR & CFI & TLI \\
\hline Model measurement & 0.817 & 0.000 & 1.000 & 0.002 & 1.000 & 1.001 \\
\hline
\end{tabular}

tem as a structural unit. To the best of our knowledge, this is the first application in a study of this nature and a major contribution to literature.

Appendix $\mathrm{C}$ is the correlation matrix showing the degree of association among variables. We found that while there is varying degree of weak association between variables, only capital and stability show a very strong positive association, however, the validity of the model results depends on the fitness of the model as presented in Table 1.

In terms of model fitness, many goodness of fit models have been proposed in literature as mentioned in subsection 2.1. But a couple of the indi- cators presented in Table 1 are considered fundamental for any SEM fitness, because they are adjudged to be the most informative (Barbara, 2001; Fan, Thompson, \& Wang, 1999; Marsh et al., 1996; Jaccard \& Wan, 1996). In terms of the psychometric properties, all the data measurement model fit showed acceptable results for the observed variables examined. The overall model fitness explained by LR chi2 prob of 0.817 indicated that the model is very fit, as null hypothesis requires the prob to be $>0.05$. Moreover, the Root Mean Square Error of Approximation (RMSEA) often used as a better approach for testing the fitness of large datasets of SEM model is found to be 0.000 indicating exact fit or absence of misfit. The rule

Source: Author's SEM estimation output (2018).

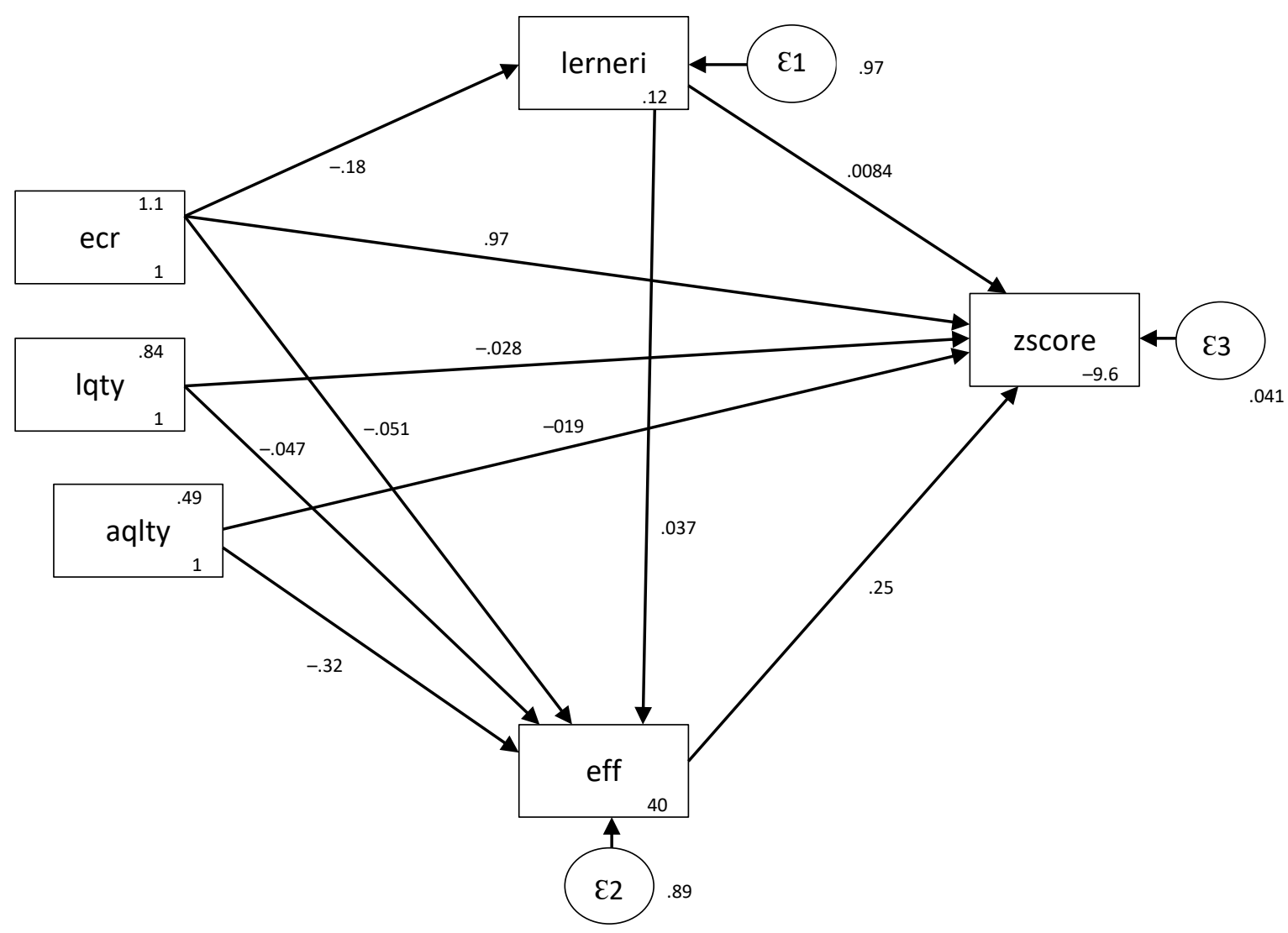

Figure 2. CERS model

5 Model fitness indices presented in Table 1 were achieved by eliminating the paths of LQTY and AQLTY to LERNERI. 
of thumb is for RMSEA to be $<0.05$ for a model to be considered good fit (Brown \& Cudeck, 1993; Marais \& Andrich, 2007, among others). PCLOSE is the p-value for testing the null hypothesis that the population RMSEA is not $>0.05$, which is expected to be $>0.50$, and substantiates the exact fit of our model, as it is 1.000 in our study, a further confirmation of model fitness. The Standardized Root Mean Square Residual (SRMSR) provides absolute measure of fit; it is the standardized difference between the predicted correlation and the observed correlation. Because it is an absolute measure, a value of 0 equals perfect fit, but $(\mathrm{Hu}$ $\&$ Bentler, 1999) suggests a value $<0.08$ as generally considered to be a good fit. Our results show SRMSR not to be different from 0 . Other tests of fitness used are Comparative Fit Index (CFI) and Tucker Lewis Index (TLI); they are both incremental measures of fits that examine the discrepancy between the data and the model hypothesized. They range from 0 to 1 , and specifically values $>0.95$ are considered very good fit, and where greater, they are restricted to 1 .

\subsection{Interpretation and discussion of SEM results}

Having been satisfied with model fitness, the proposed CERS model estimates are presented in Table 2 to show the probability values. The boxes in Figure 2 represent the interplay of the exogenous, endogenous and/or mediating variables. The arrows linking variables in the structural model depict the direction of causality between variables in the system displaying the standardized coefficients or the standardized regression weights as shown in Table 2. The underlying goodness of fit indices confirms a good fit of the structural model to the data used. All the variables are observed; in other words, they are variables with datasets. Capital (ECR), liquidity (LQTY) and asset quality (AQLTY) are exogenous regulatory variables, while competition (LERNERI) and efficiency (EFF) are endogenous variables that also predict other endogenous variables, stability (ZSCORE).

Furthermore, all the paths allowed to be fitted by the model fit criteria are found to be statistically significant with signs and magnitude shown in Table 2. Specifically, regulatory variables are shown to have a strong and direct influence on the competition, efficiency and stability variables, except that liquidity and asset quality did not cause competition and/or market power. The path of the direct influence includes: capital to competition through efficiency to stability with both liquidity and asset quality to stability through efficiency. Likewise, both the competition and efficiency variables have a strong and direct influence on stability with LERNERI directly causing ZSCORE with EFF also causing ZSCORE, given the path of both competition and efficiency to stability. Figure 2 contains seven mediating paths: $E C R \rightarrow L E R N E R I \rightarrow$ ZSCORE, having competition partially mediating the effects of capital regulation on stability; LERNERI $\rightarrow E F F \rightarrow Z S C O R E$, with efficiency partly mediating; and ECR $\rightarrow$ LERNERI $\rightarrow E F F \rightarrow$ ZSCORE, having competition and efficiency partly mediating the effects. Others are: $E C R \rightarrow L E R N E R I \rightarrow E F F$, with competition partially mediating the effects of capital on efficiency; $E C R \rightarrow E F F \rightarrow Z S C O R E$, having efficiency also partially mediating capital and stability relationship. Furthermore, the path $L Q T Y \rightarrow E F F \rightarrow$ ZSCORE shows efficiency to partly mediate liquidity regulation and stability relationship, while AQLTY $\rightarrow E F F \rightarrow Z S C O R E$ depicts that the effects of asset quality regulation are partially mediated by the efficiency variable. Overall, all effects (total, direct and indirect effects) on the links among the variables in the CERS model are found to be significant. It therefore suggests the presence of partial mediation in the structural model. Competition partially mediates the influence of capital on stability, efficiency partially mediates the effects of competition on stability, and competition-efficiency partially mediates the effects of capital on stability. In terms of causality, capital regulation causes competition, which in turn causes efficiency and then stability of the bank system. This confirms competition-stability views hypothesis in the commercial banks of SSA region and the reference to competition and stability as the reasons for capital regulation.

This study also extends extant literature by establishing direct and mediating effects among other regulatory variables (liquidity and asset quality), efficiency and stability supporting one of our hypotheses in subsection 2.1. While we do not find any causality/path running from liquidity and asset quality to competition, they however both 
Source: Authors' estimation (2018).

\begin{tabular}{|c|c|c|c|c|c|c|c|c|c|c|c|c|}
\hline \multirow{2}{*}{ Variables } & \multicolumn{3}{|c|}{ Coefficient estimates } & \multicolumn{3}{|c|}{ Direct effects } & \multicolumn{3}{|c|}{ Indirect effects } & \multicolumn{3}{|c|}{ Total effects } \\
\hline & LERNERI & EFF & ZSCORE & LERNERI & EFF & ZSCORE & LERNERI & EFF & ZSCORE & LERNERI & EFF & ZSCORE \\
\hline \multirow[t]{2}{*}{ LERNERI } & & $0.0373^{* *}$ & $0.00839^{* *}$ & & $0.0373^{* *}$ & $0.00839^{* *}$ & & & $0.00914^{* *}$ & & $0.0373^{* *}$ & $0.0175^{* * *}$ \\
\hline & & $(0.170)$ & $(0.00368)$ & & $(0.0000622)$ & $(0.0017)$ & & & $(0.00193)$ & & $(0.0000622)$ & $(0.00257)$ \\
\hline \multirow[t]{2}{*}{ EFF } & & & $0.245^{* * *}$ & & & $0.245^{* * *}$ & & & & & & $0.245^{* * *}$ \\
\hline & & & $(0.00485)$ & & & $(0.00485)$ & & & & & & $(0.00485)$ \\
\hline \multirow[t]{2}{*}{ ECR } & $-0.177^{* * *}$ & $-0.0509^{* * *}$ & $0.971^{* * *}$ & $-0.177^{* * *}$ & $-0.0508^{* * *}$ & $0.971^{* * *}$ & & $-0.00657^{* *}$ & $-0.0156^{* * *}$ & $-0.177^{* * *}$ & $-0.0574^{* * *}$ & $0.956^{* * *}$ \\
\hline & $(0.017)$ & $(0.0179)$ & $(0.00416)$ & (0.803) & (0.003) & $(0.0823)$ & & $(0.000516)$ & (0.0935) & $(0.803)$ & $(0.00296)$ & $(0.122)$ \\
\hline \multirow[t]{2}{*}{ LQTY } & & $-0.0467^{* * *}$ & $-0.0284^{* * *}$ & & $-0.0467^{* * *}$ & $-0.0284^{* * *}$ & & & $-0.0115^{* * *}$ & & $-0.0467^{* * *}$ & $-0.0398^{* * *}$ \\
\hline & & $(0.0176)$ & $(0.00381)$ & & (0.000886) & $(0.0242)$ & & & $(0.0276)$ & & $(0.000886)$ & $(0.0367)$ \\
\hline \multirow[t]{2}{*}{ AQTY } & & $-0.317^{* * *}$ & $-0.0193^{* * *}$ & & $-0.317^{* * *}$ & $-0.0193^{* * *}$ & & & $-0.0779^{* * *}$ & & $-0.317^{* * *}$ & $-0.0972^{* * *}$ \\
\hline & & $(0.0155)$ & $(0.00382)$ & & $(0.00926)$ & $(0.267)$ & & & $(0.3004)$ & & $(0.00926)$ & $(0.0383)$ \\
\hline \multirow[t]{2}{*}{ Constant } & $0.123^{* * *}$ & $39.867^{* * *}$ & $-9.63^{* * *}$ & & & & & & & & & \\
\hline & $(0.025)$ & $(0.493)$ & $(0.153)$ & & & & & & & & & \\
\hline Observation & 3,165 & 3,165 & 3,165 & 3,165 & 3,165 & 3,165 & 3,165 & 3,165 & 3,165 & 3,165 & 3,165 & 3,165 \\
\hline
\end{tabular}

Note: Standard errors in parentheses; ${ }^{* *} \mathrm{p}<0.01,{ }^{* *} \mathrm{p}<0.05,{ }^{\star} \mathrm{p}<0.1$. 
cause efficiency and stability directly and indirectly. Statistically, the indirect paths from regulation to stability better explain the fluctuations in the workings of the bank system internal mechanisms utilizing competition and efficiency as mediating variables. Hence, the results provide evidence to substantiate some of the views in literature relating capital regulation to competition and stability (see Hellmann, Murdock, \& Stiglitz, 2000; Allen \& Gale, 2004; Hakenes \& Schnabel, 2011). More importantly, the results reiterate Matutes and Vives (2000) and Repullo (2004) arguments that capital regulation may not be enough to ensure the ongoing stability of banks, as results demonstrate the explanatory influences of liquidity and assets quality regulations, notwithstanding the dominance of impact capital regulation (in terms of parameter estimates, see Figure 2 and Table 2).

The major conclusion of this study is that the mechanism of regulation, competition and sta- bility in the bank systems operates simultaneously. The implication is that change in policies targeted on any of the components affects the others either instantly or remotely. A further conclusion from the above findings is on the role of competition-efficiency relationship in partly mediating the effects of regulation and stability. As much as regulation directly impacts stability, the influence becomes mediated by competition and efficiency; this again points to the stance in literature that competition may not be the major cause of instability, but that its presence may aggravate it. Moreover, the mediating/transmitting role of efficiency in competition and stability relationship suggests that competition may not in itself cause stability unless efficiency is engendered. The policy implications are enormous for practitioners and regulators alike with further research needed to unbundle how policies should be crafted to address these issues.

\section{CONCLUSION}

The essence of this study was to explore the interplay among competition, regulation and stability to enable us to propose a model that could assist policy makers to deal with the issues of stimulating competition without compromising stability in the banking sector. Based on theories, models and extant empirical literature, we fitted a structural equation model to analyze the contemporaneous relationship among competition-efficiency, regulation and stability for the commercial banking sectors of the SSA region. Having established overall goodness of fit of the model, the results show all variables in the structure to be statistically significant. In other words, decisions that affect the exogenous variables (regulation, competition and efficiency) will have simultaneous corresponding effects on the endogenous variables (competition, efficiency and stability) within the banking system. Furthermore, mediating effects became apparent in the results with competition and efficiency partially mediating the impact of capital regulation on banks stability. Hence, we concluded a strong interrelationship among competition, regulation and stability in the banking system.

Obviously, stimulating competition in the banking system without compromising stability constitutes a major puzzle that bank regulators and practitioners face. Therefore, the application of SEM to simultaneously analyze competition, regulation and stability in banks is apt, the result that competition affects stability via efficiency and that regulation affects stability via competition and efficiency, is as well novel, producing critical theoretical and methodological insights with substantial implications for the conduct of bank regulation policy. Even though the degree of influence among variables differs, especially for capital regulation, we recommend that policies should not consider these issues in isolation, but address them holistically, if the bank system is to function at the optimal capacity that could engender the much-anticipated growth and development in the region. Given the enormous challenge in dealing with the balancing act expected to optimize the working of these relationships, we recommend further research work as an offshoot to unbundle the management and implementation process. 


\section{REFERENCES}

1. Abdelkader, I. B., \& Mansouri, F. (2013). Competitive conditions of the Tunisian banking industry: An application of the Panzar-Rosse model. African Development Review, 25(4), 526-536. https://doi. org/10.1111/1467-8268.12047

2. Agoraki, M.-E. K., Delis, M. D., \& Pasiouras, F. (2011). Regulations, competition and bank risk-taking in transition countries. Journal of Financial Stability, 7(1), 3848. https://doi.org/10.1016/j. jfs.2009.08.002

3. Aigner, D., Lovell, C. K., \& Schmidt, P. (1977). Formulation and estimation of stochastic frontier production function models. Journal of Econometrics, 6(1), 21-37. https://doi.org/10.1016/03044076(77)90052-5

4. Ajisafe, R. A., \& Akinlo, A. E. (2013). Testing for competition in the Nigerian commercial banking sector. Modern Economy, 04(07), 501-511. https://doi. org/10.4236\%2Fme.2013.47054

5. Allen, F., \& Carletti, E. (2013). New theories to underpin financial reform. Journal of Financial Stability, 9(2), 242-249. https://doi. org/10.1016/j.jfs.2011.07.001

6. Allen, F., \& Gale, D. (2004). Competition and financial stability. Journal of Money, Credit, and Banking, 36(3), 453-480.

7. Angkinand, A. P. (2009). Banking regulation and the output cost of banking crises. Journal of International Financial Markets, Institutions and Money, 19(2), 240-257. https://doi.org/10.1016/j. intfin.2007.12.001

8. Ariss, R. T. (2010). On the implications of market power in banking: Evidence from developing countries. Journal of Banking \& Finance, 34(4), 765-775. https://doi.org/10.1016/j.jbankfin.2009.09.004

9. Barbara, M. B. (2001). Structural equation modeling with AMOS: Basic concepts, applications, and programming. London: Lawrence Erlbaum Association-Publisher.
10. Barro, J., \& Barro, R. (1990). Pay, performance, and turnover of bank CEOs (Tech. Rep.). https://doi. org/10.3386\%2Fw3262

11. Barth, J. R., Caprio, G., \& Levine, R. (2004). Bank regulation and supervision: what works best? Journal of Financial Intermediation, 13(2), 205-248. https://doi. org/10.1016/j.jfi.2003.06.002

12. Battese, G. E., \& Coelli, T. J. (1992). Frontier production functions, technical efficiency and panel data: with application to paddy farmers in India. In International applications of productivity and efficiency analysis (pp. 149-165). Springer. https:// doi.org/10.1007/978-94-017-19230_10

13. Battese, G. E., \& Coelli, T. J. (1995). A model for technical inefficiency effects in a stochastic frontier production function for panel data. Empirical Economics, 20(2), 325-332. https://doi.org/10.1007/ bf01205442

14. Beck, T., \& Cull, R. (2013). Banking in Africa. In the Oxford Handbook of Banking (2nd ed.).

15. Beck, T., De Jonghe, O., \& Schepens, G. (2013). Bank competition and stability: crosscountry heterogeneity. Journal of Financial Intermediation, 22(2), 218-244. https://doi.org/10.1016/j. jfi.2012.07.001

16. Berger, A. N., \& Udell, G. F. (2004). The institutional memory hypothesis and the procyclicality of bank lending behavior. Journal of Financial Intermediation, 13(4), 458-495. https://doi.org/10.1016/j. jfi.2004.06.006

17. Berger, A. N., Klapper, L. F., \& Turk-Ariss, R. (2008). Bank competition and financial stability. Journal of Financial Services Research, 35(2), 99-118. https://doi. org/10.1007/s10693-008-0050-7

18. Bolt, W., \& Tieman, A. F. (2004). Banking competition, risk and regulation. The Scandinavian Journal of Economics, 106(4), 783-804. https://doi.org/10.1111/ j.0347-0520.2004.00388.x
19. Boyd, J. H., \& De Nicoló, G. (2005). The theory of bank risk-taking and competition revisited. The Journal of Finance, 60(3), 1329-1343. https://doi.org/10.1111/j.15406261.2005.00763.x

20. Boyd, J. H., De Nicoló, M. G., \& Jalal, A. M. (2009). Bank competition, risk and asset allocations (No. 9-143). International Monetary Fund. https://doi. org/10.5089/9781451872903.001

21. Bresnahan, T. F. (1982). The oligopoly solution concept is identified. Economics Letters, 10(1), 87-92. https://doi. org/10.1016/0165-1765(82)90121-5

22. Brown, M. W., \& Cudeck, R. (1993). Alternative ways of assessing model fit. Testing Structural Equation Models, 154, 136-162.

23. Carbó, S., Humphrey, D., Maudos, J., \& Molyneux, P. (2009). Cross-country comparisons of competition and pricing power in European banking. Journal of International Money and Finance, 28(1), 115-134. https://doi.org/10.1016/j.jimonfin.2008.06.005

24. Carletti, E. (2008). Competition and regulation in banking. Handbook of Financial Intermediation and Banking, 449482.

25. Casu, B., Girardone, C., \& Molyneux, P. (2015). Introduction to banking (Vol. 10). Pearson Education.

26. Chang, C., Lee, A. C., \& Lee, C. F. (2009). Determinants of capital structure choice: A structural equation modeling approach. The Quarterly Review of Economics and Finance, 49(2), 197-213. https://doi.org/10.1016/j. qref.2008.03.004

27. Chiou, W.-J. P., \& Porter, R. L. (2015). Does banking capital reduce risk? An application of stochastic frontier analysis and GMM approach. In Handbook of financial econometrics and 
statistics (pp. 349-382). Springer https://doi.org/10.1007/978-14614-7750-1_13

28. Chirwa, E. W. (2003).

Determinants of commercial banks' profitability in Malawi: A cointegration approach. Applied Financial Economics, 13(8), 565 571. https://doi.org/10.1080/09603 10022000020933

29. Cihak, M., Demirgüç-Kunt, A., Martinez Peria, M. S., \& Mohseni-Cheraghlou, A. (2012) Bank regulation and supervision around the world: a crisis update (World Bank Policy Research Working Paper 6286). https://doi. org/10.1596/1813-9450-6286

30. Coelli, T. J. (1996). A guide to frontier version 4.1: a computer program for stochastic frontier production and cost function estimation (Tech. Rep.). CEPA Working papers.

31. Delis, M. D., Staikouras, K. C., \& Varlagas, P. T. (2008). On the measurement of market power in the banking industry. Journal of Business Finance \& Accounting, 35(7-8), 1023-1047. https://doi.org/10.1111/j.14685957.2008.02098.x

32. Dell'Ariccia, G., \& Marquez, R. (2006). Lending booms and lending standards. The Journal of Finance, 61(5), 2511-2546. https://doi.org/10.1111/j.15406261.2006.01065.x

33. Demirgüç-Kunt, A., \& Peria, M. S. M. (2010). A framework for analyzing competition in the banking sector: $A n$ application to the case of Jordan. The World Bank. https://doi. org/10.1596\%2F1813-9450-5499

34. Demsetz, H. (1973). Industry structure, market rivalry, and public policy. The Journal of Law \& Economics, 16(1), 1-9. https:// doi.org/10.1086/466752

35. Fan, X., Thompson, B., \& Wang, L. (1999). Effects of sample size, estimation methods, and model specification on structural equation modeling fit indexes. Structural Equation Modeling: A Multidisciplinary Journal, 6(1), 56-83. https://doi. org/10.1080/10705519909540119
36. Freixas, X., Rochet, J.-C. et al. (2008). Microeconomics of banking (Vol. 2). Cambridge, MA: MIT press.

37. Fu, X. M., Lin, Y. R., \& Molyneux, P. (2014). Bank competition and financial stability in Asia Pacific. Journal of Banking \& Finance, 38, 64-77. https://doi.org/10.1016/j. jbankfin.2013.09.012

38. Hakenes, H., \& Schnabel, I. (2011). Capital regulation, bank competition, and financial stability. Economics Letters, 113(3), 256-258 https://doi.org/10.1016/j.econlet.2011.07.008

39. Hellmann, T. F., Murdock, K. C., \& Stiglitz, J. E. (2000). Liberalization, moral hazard in banking, and prudential regulation: Are capital requirements enough? American economic review, 147-165. https:// doi.org/10.1257/aer.90.1.147

40. Hicks, J. R. (1935). Annual survey of economic theory: the theory of monopoly. Econometrica: Journal of the Econometric Society, 1-20.

41. Hu, L.-t., \& Bentler, P. M. (1999). Cut-off criteria for fit indexes in covariance structure analysis: Conventional criteria versus new alternatives. Structural Equation Modeling: A Multidisciplinary Journal, 6(1), 1-55. https://doi. org/10.1080/10705519909540118

42. $\operatorname{IMF}(2016$, October). World Economic Outlook: Subdued Demand-Symptoms and Remedies.

43. Jaccard, J., \& Wan, C. (1996). LISREL approaches to interaction effects in multiple regression. SAGE Publications, Inc. https://doi. org/10.4135\%2F9781412984782

44. Kim, D., \& Santomero, A. M. (1988). Risk in banking and capital regulation. The Journal of Finance, 43(5), 1219-1233. https:// doi.org/10.1111/j.1540-6261.1988. tb03966.x

45. Kouki, I., \& Al-Nasser, A. (2014). The implication of banking competition: Evidence from African countries. Research in International Business and Finance, 39, 878-895. https://doi.org/10 .1016\%2Fj.ribaf.2014.09.009
46. Laeven, L., \& Levine, R. (2009). Bank governance, regulation and risk taking. Journal of Financial Economics, 93(2), 259-275. https://doi.org/10.1016/j.jfineco.2008.09.003

47. Lepetit, L., \& Strobel, F. (2013). Bank insolvency risk and timevarying z-score measures. Journal of International Financial Markets, Institutions and Money, 25, 73-87. https://doi.org/10.1016/j.intfin.2013.01.004

48. Li, S. D. (2011). Testing mediation using multiple regression and structural equation modeling analyses in secondary data. Evaluation Review, 35(3), 240-268. https://doi. org/10.1177/0193841x11412069

49. Liu, H., \& Wilson, J. O. (2013). Competition and risk in Japanese banking. The European Journal of Finance, 19(1), 1-18. https://doi.or g/10.1080/1351847x.2011.633614

50. Llewellyn, D. (1999). The economic rationale for financial regulation. London: Financial Services Authority.

51. Marais, I., \& Andrich, D. R. (2007). Rasch unidimensional measurement models simulation studies software. Perth: The University of Western Australia.

52. Marsh, H. W., Balla, J. R., \& Hau, K.-T. (1996). An evaluation of incremental fit indices: A clarification of mathematical and empirical properties. Advanced Structural Equation Modeling: Issues and Techniques, 315-353.

53. Martinez-Miera, D., \& Repullo, R. (2010). Does competition reduce the risk of bank failure? Review of Financial Studies, 23(10), 36383664. https://doi.org/10.1093/rfs/ hhq057

54. Matutes, C., \& Vives, X. (2000). Imperfect competition, risk taking, and regulation in banking. European Economic Review, 44(1), 1-34. https://doi.org/10.1016/ s0014-2921(98)00057-9

55. Meeusen, W., \& van Den Broeck, J. (1977). Efficiency estimation from Cobb-Douglas production functions with composed error. International Economic 
Review, 435-444. https://doi. org/10.2307/2525757

56. Mehrotra, A. N., \& Yetman, J. (2015). Financial inclusion-issues for central banks.

57. Mlachila, M., Dykes, D., Zajc, S., Aithnard, P.-H., Beck, T., Ncube, M., \& Nelvin, O. (2013). Banking in Sub-Saharan Africa: Challenges and opportunities (Tech. Rep.) European Investment Bank (EIB). Retrieved from http://hdl.handle. net/10419/88938

58. Moyo, J., Nandwa, B., Council, D. E., Oduor, J., \& Simpasa, A. (2014). Financial sector reforms, competition and banking system stability in Sub-Saharan Africa. New Perspectives.

59. Mueller, R. O. (1999). Basic principles of structural equation modeling: An introduction to lisrel and eqs. Springer Science \& Business Media.

60. Mugume, A. (2008). Market structure and performance in Uganda's banking industry. African Econometrics Society. Retrieved from pdfs.semanticscholar.org

61. Prasad, A., \& Ghosh, S. (2005). Competition in Indian banking
(No. 2005-2141). International Monetary Fund. https://doi. org/10.5089/9781451861600.001

62. Repullo, R. (2004). Capital requirements, market power, and risk-taking in banking. Journal of Financial Intermediation, 13(2), 156-182. https://doi.org/10.1016/j. jfi.2003.08.005

63. Rojas, C. (2011). Market power and the Lerner index: a classroom experiment. Journal of Industrial Organization Education, 5(1), 1-19. https://doi.org/10.2202/19355041.1033

64. Schaeck, K., \& Cihák, M. (2014). Competition, efficiency, and stability in banking. Financial Management, 43(1), 215241. https://doi.org/10.1111/ fima.12010

65. Shepherd, W. G. (1983). Economies of scale and monopoly profits. In Industrial organization, antitrust, and public policy (pp. 165-204). Springer.

66. Tan, Y. (2013). Essays on the analysis of performance and competitive condition in the Chinese banking industry (Unpublished doctoral thesis). University of Portsmouth.
67. Vives, X. (2014). Strategic complementarity, fragility, and regulation. Review of Financial Studies, 27(12), 3547-3592. https://doi.org/10.1093/rfs/ hhu064

68. Vives, X. (2016a). Competition and stability in banking (No. 70-105). New Jersey: Princeton University Press.

69. Vives, X. (2016b). Competition and stability in banking: The role of regulation and competition policy. New Jersey: Princeton University Press.

70. Wang, X., Zeng, X., \& Zhang, Z. (2014). The influence of the market power of Chinese commercial banks on efficiency and stability. China Finance Review International, 4(4), $307-$ 325. https://doi.org/10.1108/cfri07-2013-0096

71. Watkins, K. (2014). Grain, fish money: financing Africa's green and blue revolutions: Africa progress report 2014.

72. World Bank (2017). World Bank Country Profile Overview. 


\section{APPENDIX}

\section{Appendix A. Banks selection}

Table 1. Number of banks per SSA countries

Source: Based on data collected from BankScope

\begin{tabular}{|c|c|c|}
\hline No. & Country & Number of banks \\
\hline 1 & Angola & 21 \\
\hline 2 & Benin & 10 \\
\hline 3 & Botswana & 10 \\
\hline 4 & Burkina Faso & 10 \\
\hline 5 & Cameroon & 12 \\
\hline 6 & Central African Republic & 2 \\
\hline 7 & Cape Verde & 6 \\
\hline 8 & Chad & 5 \\
\hline 9 & Djibouti & 5 \\
\hline 10 & Ethiopia & 12 \\
\hline 11 & Equatorial Guinea & 3 \\
\hline 12 & Gabon & 7 \\
\hline 13 & Ghana & 28 \\
\hline 14 & Guinea & 4 \\
\hline 15 & Guinea-Bissau & 1 \\
\hline 16 & Ivory Coast & 17 \\
\hline 17 & Kenya & 42 \\
\hline 18 & Lesotho & 4 \\
\hline 19 & Liberia & 6 \\
\hline 20 & Malawi & 12 \\
\hline 21 & Mali & 9 \\
\hline 22 & Mauritania & 9 \\
\hline 23 & Mauritius & 20 \\
\hline 24 & Mozambique & 14 \\
\hline 25 & Namibia & 8 \\
\hline 26 & Niger & 5 \\
\hline 27 & Nigeria & 20 \\
\hline 28 & Rwanda & 8 \\
\hline 29 & Senegal & 15 \\
\hline 30 & Seychelles & 6 \\
\hline 31 & Sierra Leone & 10 \\
\hline 32 & Swaziland & 4 \\
\hline 33 & Tanzania & 35 \\
\hline 34 & The Gambia & 8 \\
\hline 35 & Togo & 7 \\
\hline 36 & Uganda & 25 \\
\hline 37 & Zambia & 20 \\
\hline \multicolumn{2}{|r|}{ Total } & 440 \\
\hline
\end{tabular}




\section{APPENDIX B. SUMMARY STATISTICS}

Table 2. Summary statistics

Source: Authors' estimation (2018).

\begin{tabular}{|c|c|c|c|c|c|c|}
\hline Variables & Obs. & Mean & Std. Dev. & Min. & Max. & Jarque-Bera \\
\hline ZSCORE & 3,165 & 3.3553 & 3.064947 & -17.89 & 35.629 & 0.0000 \\
\hline LERNERI & 3,165 & 0.3 & 0.19334 & 0 & 0.9978 & 0.0000 \\
\hline ECR & 3,165 & 0.1545 & 0.144056 & -0.454 & 0.9986 & 0.0000 \\
\hline LQTY & 3,165 & 0.4064 & 0.481929 & $-8 \mathrm{E}-04$ & 8.8824 & 0.0000 \\
\hline AQLTY & 3,165 & 0.0213 & 0.043818 & -0.892 & 0.6635 & 0.0000 \\
\hline EFF & 3,165 & 0.9572 & 0.024162 & 0.6573 & 1 & 0.0000 \\
\hline
\end{tabular}

\section{APPENDIX C. CORRELATION ANALYSIS}

Table 3. Correlation analysis

Source: Authors' estimation (2018).

\begin{tabular}{|c|c|c|c|c|c|c|}
\hline Variables & ECR & LQTY & AQLTY & LERNERI & EFF & ZSCORE \\
\hline ECR & 1.0000 & 0.31242 & -0.021381 & -0.176526 & -0.065236 & 0.945292 \\
\hline LQTY & 0.31242 & 1.0000 & 0.038314 & -0.045985 & -0.076470 & 0.255193 \\
\hline AQLTY & -0.021381 & 0.038314 & 1.0000 & 0.009755 & -0.317865 & -0.119063 \\
\hline LERNERI & -0.176526 & -0.045985 & 0.009755 & 1.0000 & 0.045299 & -0.150826 \\
\hline EFF & -0.065236 & -0.076470 & -0.317865 & 0.045299 & 1.0000 & 0.190637 \\
\hline ZSCORE & 0.945292 & 0.255193 & -0.119063 & -0.150826 & 0.190637 & 1.0000 \\
\hline
\end{tabular}

